\title{
Purification and Characterization of a
}

\section{Human Neutrophil Neutral Protease}

\author{
THE NEUTRAL PEPTIDE-GENERATING PROTEASE
}

\author{
Jonathan S. Coblyn, K. Frank Austen, and Bruce U. Wintroub, \\ Departments of Dermatology and Medicine, Harvard Medical School, and the \\ Department of Medicine, Robert B. Brigham Division, and the Divisions of \\ Dermatology, Robert B. Brigham and Peter Bent Brigham Divisions of the \\ Affiliated Hospitals Center, Inc., Boston, Massachusetts 02120
}

\begin{abstract}
A B S T RACT A human neutrophil neutral protease which generates a low molecular weight peptide from a plasma protein substrate and cleaves the basic amino acid ester substrates $\alpha$ - $N$ - $p$-tosyl-L-arginine methyl ester $\mathrm{HCl}, \alpha$ - $N$-benzoyl-L-arginine-methyl ester $\mathrm{HCl}$, and $\alpha-N$-carbobenzoxy-L-lysine- $p$-nitrophenyl ester has been purified to homogeneity and distinguished from the known lysosomal neutrophil proteases. The starting activity was obtained from purified human neutrophils by homogenization, sedimentation by lowspeed centrifugation, and high salt elution of the insoluble material. Purification was achieved by aprotinin-affinity chromatography, precipitation at low ionic strength, and gel filtration. The overall recovery, relative to the activity in the starting eluate of the neutrophil fraction, was $\cong 50 \%$ with a 200 - to 400 -fold increase in specific activity. After treatment with diisopropylfluorophosphate to eliminate autodegradation, sodium dodecyl sulfate-polyacrylamide gel electrophoresis of reduced and unreduced protein gave a single protein band of $29,000-30,000 \mathrm{~mol}$ wt. The isoelectric point determined in sucrose gradients ranged from $\mathrm{pH} 7.8$ to 8.3 with a peak at $\mathrm{pH}$ 8.0. This neutrophil protease, like cathepsin $\mathrm{G}$ and elastase, is composed of a single polypeptide chain of $\cong 30,000 \mathrm{~mol}$ wt, but differs from cathepsin $\mathrm{G}$ and elastase in its less cationic isoelectric point and its failure to cleave synthetic substrates presenting an aromatic amino acid ester linkage and alanyl peptide bonds, respectively.
\end{abstract}

Dr. Coblyn is a postdoctoral trainee supported by training grant AM-07031 from the National Institutes of Health. Dr. Wintroub is the recipient of a Clinical Investigator Award (AM-00430) from the National Institutes of Health.

Received for publication 1 December 1978 and in revised form 17 January 1979.

\section{INTRODUCTION}

Human neutrophils exhibit a variety of degradative and effector functions, many of which are attributed to lysosomal components, which are broadly divided into neutral proteases and acid hydrolases (1). Purification and antigenic identification of enzymes from different tissue sources have shown a broad substrate specificity for at least two of the lysosomal neutral proteases. Elastase hydrolyzes elastin, collagen, proteoglycan, azo-casein (2), hemoglobin, fibrinogen $(3,4)$, and histone (5). Cathepsin G, which is separable from elastase, hydrolyzes hemoglobin and fibrinogen (3), casein (6), azo-casein, collagen, and proteoglycan (7). A third neutral protease with collagenolytic activity has been distinguished from elastase and cathepsin $G$ on the basis of its greater size and different substrate specificity (8). Lysosomal contents may be released from neutrophils during phagocytosis (9), or after intensive stimulation by chemotactic factors alone (10).

The neutral peptide-generating system which is expressed by intact unstimulated neutrophils represents a pathway by which this cell may interact with extracellular proteins without requiring a degranulating stimulus (11). In this pathway a neutrophil protease interacts with a plasma protein substrate to generate a biologically active neutral peptide product with a mol wt of $1,000(11,12)$. The peptide has an isoelectric point of $\mathrm{pH} 7.2$, contracts the guinea pig ileum in preference to the estrous rat uterus, and enhances vascular permeability when injected into guinea pig skin (12). The reaction is regulated by two normally occurring plasma proteins: $\alpha$-1-antitrypsin, an inhibitor of the neutral peptide-generating protease, and an inactivator of the neutral peptide (12). The neutral peptidegenerating protease has now been purified to homo- 
geneity and may be distinguished from human neutrophil elastase, cathepsin $\mathrm{G}$, and collagenase on the basis of physicochemical characteristics and substrate specificity.

\section{METHODS}

Bradykinin triacetate (Sandoz Pharmaceuticals, Ltd., Basel, Switzerland); diisopropylfluorophosphate (DFP, ${ }^{1}$ Aldrich Chemical Co., Inc., Milwaukee, Wis.); sucrose and Tris (Fisher Scientific Co., Pittsburgh, Pa.); aprotinin (Trasylol; bovine Kunitz basic pancreatic trypsin inhibitor, a gift of Professor Gert L. Haberland, Bayer AG, Wuppertal, West Germany); 4,5dihydroxy-2,7-naphthalene disulfonic acid (chromotropic acid), glacial acetic acid (Eastman Organic Chemicals Div., Eastman Kodak Co., Rochester, N. Y.); ampholine carrier ampholytes (LKB Instruments, Inc., Rockville, Md.), Sephadex G-100, Ficoll-Hypaque, activated CH-Sepharose 4B, quaternary aminoethyl Sephadex, Sephacryl S-200, Affi-Gel Blue, and protein-sizing standards (Pharmacia Fine Chemicals, Div. of Pharmacia Inc., Piscataway, N. J.); human serum albumin (Schwartz/Mann Div., Becton, Dickinson \& Co., Orangeburg, N. Y.); Hanks' balanced salt solution (Microbiological Associates, Walkersville, Md.); $\alpha$ - $N$ - $p$-tosyl-L-arginine methyl ester $\mathrm{HCl}$ (TAMe), $\alpha$ - $N$-benzoyl-L-arginine-methyl ester $\mathrm{HCl}$ (BAMe), $N$-benzoyl-L-tyrosine ethyl ester (BTEE), L-1tosylamide-2-phenylethylchloromethyl ketone, $N-\alpha-p$-tosyl-Llysine chloromethyl ketone $\mathrm{HCl}, N$-t-Boc-L-alanine $p$-nitrophenyl ester (Sigma Chemical Co., St. Louis, Mo.); porcine elastase, orcein-elastin (Worthington Biochemical Corp., Freehold, N. J.); $N$-succinyl-(L-ala) ${ }_{3}-p$-nitroanilide (suc-[ala $]_{3}$ pNA, Calbiochem-Behring Corp., American Hoechst Corp., San Diego, Calif.); Acetyl(L-alanine) ${ }_{2}$-proline-valine-chloromethyl ketone (gift of Dr. J. Powers, Atlanta, Ga.) (13); and $\alpha-N$ carbobenzoxy-L-lysine- $p$-nitrophenyl ester (CLN), Vega-Fox Biochemicals Div., Newberry Energy Corp., Tucson, Ariz.) were obtained as noted. C3 was a gift of Dr. D. T. Fearon (Boston, Mass.) and was prepared as described (14).

Assay of the neutral peptide-generating protease. The neutral peptide-generating protease was measured by its ability to generate neutral peptide from partially purified plasma protein substrate (12). During isolation of the neutral peptide-generating protease the activity was measured by a 30 -min incubation at $37^{\circ} \mathrm{C}$ with partially purified plasma substrate in $0.01 \mathrm{M}$ Tris, $\mathrm{pH} 7.2,0.15 \mathrm{M} \mathrm{NaCl}$, with a final reaction volume of $200 \mu \mathrm{l}$. After purification, the neutral peptidegenerating protease was assayed by a 7 -min incubation with the same reaction conditions. Reactions were stopped by cooling in an ice bath and the mixture was directly bioassayed for neutral peptide activity. Neutral peptide was measured by its ability to contract an isolated, atropinized, guinea pig terminal ileum (12) which had been standardized with bradykinin, and neutral peptide activity is expressed as nanogram bradykinin equivalents (ng BK eq).

The plasma protein substrate of the neutral peptidegeneratíng protease was partially purified from citrated human plasma. $200 \mathrm{ml}$ of plasma was dialyzed for $12 \mathrm{~h}$ at $4^{\circ} \mathrm{C}$ against

\footnotetext{
${ }^{1}$ Abbreviations used in this paper: BAMe, $\alpha$-N-benzoylL-arginine-methyl ester $\mathrm{HCl}$; BTEE, $N$-benzoyl-L-tyrosine ethyl ester; CLN, $\alpha$-N-carbobenzoxy-L-lysine- $p$-nitrophenyl ester; DFP, diisopropylfluorophosphate; ng BK eq, nanogram bradykinin equivalents; SDS-PAGE, sodium dodecyl sulfate polyacrylamide gel electrophoresis; Suc-(ala) ${ }_{3}$-pNA, N-Succinyl-(L-ala $)_{3}-p$-nitroanilide; TAMe, $\alpha-N$ - $p$-tosyl-L-arginine methyl ester $\mathrm{HCl}$.
}

$0.01 \mathrm{M}$ Tris, $\mathrm{pH} 7.8,0.05 \mathrm{M} \mathrm{NaCl}$, before being applied to a $5 \times 45$-cm quaternary aminoethyl Sephadex anion-exchange column equilibrated in the same buffer. The column was washed with 4 bed vol of the equilibrating buffer and batch eluted with 4 bed vol of $0.01 \mathrm{M}$ Tris, $\mathrm{pH} 7.8,0.5 \mathrm{M} \mathrm{NaCl}$. After being concentrated to $20 \mathrm{ml}$ by positive pressure, the eluted material was directly filtered at $4^{\circ} \mathrm{C}$ through a previously calibrated $5 \times 100-\mathrm{cm}$ Sephacryl S-200 column equilibrated and run in $0.01 \mathrm{M}$ Tris, $\mathrm{pH} 7.4,0.15 \mathrm{M} \mathrm{NaCl}$ at a flow rate of $60 \mathrm{ml} / \mathrm{h}$; and $20-\mathrm{ml}$ fractions were collected. Material filtering with a mol wt in the 75,000-100,000 range was pooled, concentrated to $10 \mathrm{ml}$, and then refiltered through a $2.5 \times 90-\mathrm{cm}$ Sephacryl S-200 column equilibrated and run in the same buffer at a flow rate of $20 \mathrm{ml} / \mathrm{h}$. 5-ml fractions were collected and material filtering with a mol wt in the $75,000-100,000$ range was pooled and concentrated to $10 \mathrm{ml}$ before being dialyzed for $12 \mathrm{~h}$ at $4^{\circ} \mathrm{C}$ against $0.01 \mathrm{M}$ Tris, $\mathrm{pH} 7.4,0.5 \mathrm{M} \mathrm{NaCl}$. The dialyzed material was applied to a dextran polymer blue dye affinity column prepared with $10-\mathrm{ml}$ bed vol per $10 \mathrm{mg}$ protein of the dialysate. The column was equilibrated with the dialysis buffer and washed with 10 bed vol of the equilibrating buffer. The effluent was pooled, concentrated to $10-20 \mathrm{ml}$ so that the protein concentration was $6-12 \mathrm{mg} / \mathrm{ml}$, dialyzed against $0.01 \mathrm{M}$ Tris, $\mathrm{pH} 7.4,0.15 \mathrm{M} \mathrm{NaCl}$, divided into aliquots, heated for $2 \mathrm{~h}$ at $61^{\circ} \mathrm{C}$ to inactivate inhibitors, and stored at $-70^{\circ} \mathrm{C}$ before use for detection of neutral peptide-generating protease activity.

The hydrolysis of TAMe and BAMe $(15,16), \operatorname{CLN}(17,18)$, BTEE (19), $N$-t-Boc-L-alanine $p$-nitrophenyl ester (20), and Suc-(ala) ${ }_{3}$-pNA (21) was determined as described. Elastolytic activity was measured colorimetrically with orcein-dyed elastin as substrate (22). Cleavage of $\mathrm{C} 3$ was measured with a hemolytic assay for inactivation (23).

Procedures for isolation and characterization of the neutral peptide-generating protease. Solubilized neutral peptidegenerating protease was prepared from human polymorphonuclear leukocytes which had been purified from fresh, whole citrated blood by dextran sedimentation of erythrocytes and fractionation of leukocytes by centrifugation on FicollHypaque cushions (11). $10 \mathrm{ml}$ of purified neutrophils, $10^{8} / \mathrm{ml}$, was homogenized in $0.34 \mathrm{M}$ sucrose by 60 strokes of a rotating Teflon plunger (Tri-R Instruments, Inc., Rockville Centre, $\mathrm{N}$. Y.). The homogenate was centrifuged at $100 \mathrm{~g}$ for $20 \mathrm{~min}$ at room temperature. The pellet was suspended in $10 \mathrm{ml}$ of $0.01 \mathrm{M}$ Tris, $\mathrm{pH} 7.4,1.0 \mathrm{M} \mathrm{NaCl}$, dispersed by sonication for $3 \mathrm{~min}$ at $4^{\circ} \mathrm{C}$ with a probe sonicator (Branson Sonic Power Co., Danbury, Conn.), and then eluted in the same buffer for $1 \mathrm{~h}$ at room temperature (11). The insoluble material was sedimented at $16,000 \mathrm{~g}$ for $20 \mathrm{~min}$ at $4^{\circ} \mathrm{C}$, and the supernate, which contained $90 \%$ of the neutral peptide-generating activity, was retained for aprotinin-affinity chromatography.

Aprotinin was coupled to activated CH-Sepharose 4B by a described procedure (24) which minimizes coupling via lysine epsilon amino groups of aprotinin to the CH-Sepharose 4B. A 2-g portion of lyophilized activated CH-Sepharose 4B was washed under suction in a coarse-grade Buchner fritted disk funnel with 1 liter of $0.001 \mathrm{M} \mathrm{HCl}$, rinsed with $500 \mathrm{ml}$ of icecold $0.1 \mathrm{M}$ potassium phosphate buffer, $\mathrm{pH} 6.5$, and quickly transferred to a $50-\mathrm{ml}$ plastic tube containing $15 \mathrm{ml}$ of a $2.3-\mathrm{mg} /$ $\mathrm{ml}$ solution of aprotinin in phosphate buffer cooled to $4^{\circ} \mathrm{C}$. The reactants were mixed for $2 \mathrm{~h}$ at room temperature and then for $12 \mathrm{~h}$ at $4^{\circ} \mathrm{C}$. Excess ligand was removed by washing sequentially with $75 \mathrm{ml}$ of each of the following buffers: $0.1 \mathrm{M}$ $\mathrm{NaHCO}_{3}, \mathrm{pH} 8.5 ; 0.1 \mathrm{M}$ acetate, $\mathrm{pH} 3.0,1.0 \mathrm{M} \mathrm{NaCl}$; and $0.1 \mathrm{M}$ Tris- $\mathrm{HCl}, \mathrm{pH} 8.0,0.5 \mathrm{M} \mathrm{NaCl}$. To block unreacted ester groups the aprotinin-Sepharose was incubated with $25 \mathrm{ml}$ of $1.0 \mathrm{M}$ ethanolamine, which had been adjusted to $\mathrm{pH} 8.0$ with $12 \mathrm{M} \mathrm{HCl}$, for $2 \mathrm{~h}$ at room temperature and rinsed with $200 \mathrm{ml}$ 
of and resuspended in $0.1 \mathrm{M} \mathrm{NaHCO}, \mathrm{pH} 8.0,0.5 \mathrm{M} \mathrm{NaCl}$. Excess ligand in the buffer washes was quantitated by the procedure of Lowry et al. (25). 50\% coupling was achieved yielding $\cong 0.6 \mu \mathrm{mol}$ of aprotinin $/ \mathrm{ml}$ of settled Sepharose. The aprotinin-Sepharose was stored at $4^{\circ} \mathrm{C}$ in $0.2 \mathrm{M}$ Tris, $\mathrm{pH} 8.0$, $0.5 \mathrm{M} \mathrm{NaCl}$.

All concentrations were performed with positive pressure chambers that use UM 10 membranes (Amicon Corp., Scientific Systems Div., Lexington, Mass.). Routine centrifugation was carried out in IEC clinical centrifuges at room temperature (Damon/IEC Div., Damon Corp., Needham Heights, Mass.), and in RC5 Sorvall refrigerated centrifuges (DuPont Instruments-Sorvall, Du Pont Co., Newtown, Conn.) at $4^{\circ} \mathrm{C}$. Ultracentrifugation was performed in a Beckman L-265-B ultracentrifuge (Beckman Instruments, Inc., Fullerton, Calif.). Protein concentrations were determined spectrophotometrically according to the method of Lowry et al. (25) with human serum albumin as a standard.

Analytic isoelectric focusing was performed (26) at room temperature in sucrose with a $15-\mathrm{ml}$ linear $10-40 \%$ gradient containing $4 \% \mathrm{vol} / \mathrm{vol}$ ampholytes, composed of equal volumes of ampholytes of pH 3-10 and 7-10 or of 4\% vol/ vol ampholytes pH 3-10. The gradient was prepared in a glass column at room temperature with a gradient maker (Buchler Instruments Div., Searle Diagnostics Inc., Fort Lee, N. J.). After $1 \mathrm{ml}$ of the gradient had been made, $50 \mu \mathrm{g}$ of purified neutral peptide-generating protease in $200 \mu \mathrm{l}$ of water was mixed with the $40 \%$ sucrose in the well of the gradient maker and subsequently dispersed throughout the entire gradient. To establish the gradient of ampholytes, $4.5 \mathrm{~mA}$ at $10^{\circ} \mathrm{C}$ was applied to each column until a $400-\mathrm{V}$ potential was obtained and focusing was conducted until the current stabilized for $45 \mathrm{~min}$. The gradient was aspirated from the bottom with a peristaltic pump and $0.5-\mathrm{ml}$ fractions were collected. The $\mathrm{pH}$ of every other fraction was measured, and each fraction was then neutralized by the addition of $250 \mu$ l of $1.0 \mathrm{M}$ Tris, $\mathrm{pH}$ 7.4.

Sodium dodecyl sulfate-polyacrylamide gel electrophoresis (SDS-PAGE) was carried out in $10 \%$ acrylamide gels by a modification of a previously described procedure (27). Samples were incubated in $8 \mathrm{M}$ urea for $60 \mathrm{~min}$ at $37^{\circ} \mathrm{C}$ in $0.1 \mathrm{M}$ sodium phosphate buffer, $\mathrm{pH} 7.2$ in either the presence or absence of $2 \% 2$-mercaptoethanol. Subsequent alkylation with $\mathbf{0 . 0 2 \%}$ iodoacetamide was carried out in the dark for 30 min at $4^{\circ} \mathrm{C}$. Before SDS-PAGE, all samples were made $1 \%$ in SDS. Ribonuclease A (mol wt, 13,700), chymotrypsinogen (mol wt, 25,000), ovalbumin (mol wt, 45,000), and C3 were utilized as standards. Under these reaction conditions, C3 had a mol wt of 210,000 and was completely reduced to two chains with mol wt of 140,000 and 80,000 when analyzed in 5\% SDS gels.

\section{RESULTS}

Purification of neutral peptide-generating protease. Solubilized neutral peptide-generating protease from $10^{9}$ cells was dialyzed against $0.1 \mathrm{M} \mathrm{NaHCO}_{3}, \mathrm{pH} 8.0$, $0.5 \mathrm{M} \mathrm{NaCl}$ for $3 \mathrm{~h}$ at $4^{\circ} \mathrm{C}$, brought to $25 \mathrm{ml}$ by the addition of the same buffer, and applied to a 5-ml aprotininSepharose column equilibrated with the dialysis buffer. The column was washed at $4^{\circ} \mathrm{C}$ with the dialysis buffer until protein could not be detected in the effluent. Elution was then carried out at a flow rate of 80 $\mathrm{ml} / \mathrm{h}$ at $25^{\circ} \mathrm{C}$ with $40 \mathrm{ml}$ of $0.1 \mathrm{M}$ acetate buffer, $\mathrm{pH} 4.5$, $2.0 \mathrm{M} \mathrm{NaCl}$ and 2.5-ml fractions were collected in tubes containing $0.8 \mathrm{ml}$ of $1.0 \mathrm{M}$ Tris, $\mathrm{pH} 7.5 .50-\mu \mathrm{l}$ samples of each fraction were assayed for protein and neutral peptide-generating activity (Fig. 1). The bulk of the protein was in the effluent, and a single peak of neutral peptide-generating activity was detected in the eluate in a region containing a small amount of protein.

Fractions 87-92 containing neutral peptide-generating activity were pooled, concentrated, and dialyzed against $0.1 \mathrm{M}$ Tris, $\mathrm{pH} 8.0,0.01 \mathrm{M} \mathrm{NaCl}$ for $3 \mathrm{~h}$ at $4^{\circ} \mathrm{C}$ and then ultracentrifuged at $120,000 \mathrm{~g}$ for $1 \mathrm{~h}$. The supernate was removed and the pellet was resolubilized by the addition of $1 \mathrm{ml}$ of $0.01 \mathrm{M}$ Tris, $\mathrm{pH}$ $7.4,1.0 \mathrm{M} \mathrm{NaCl}$. More than $90 \%$ of the neutral peptidegenerating activity was contained in the resolubilized pellet and $<10 \%$ remained in the supernate. The resolubilized protease was filtered at room temperature through a previously calibrated $1.5 \times 90-\mathrm{cm}$ Sephadex

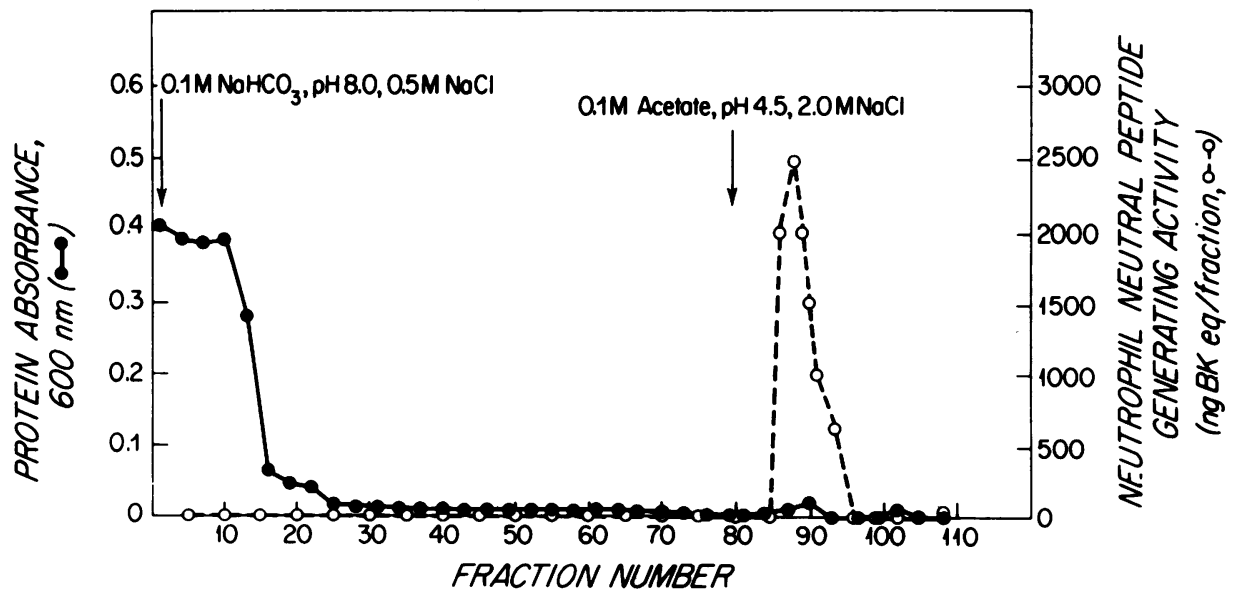

FIGURE 1 Aprotinin-affinity chromatography of the eluted 100-g pellet of homogenized purified human neutrophils. 


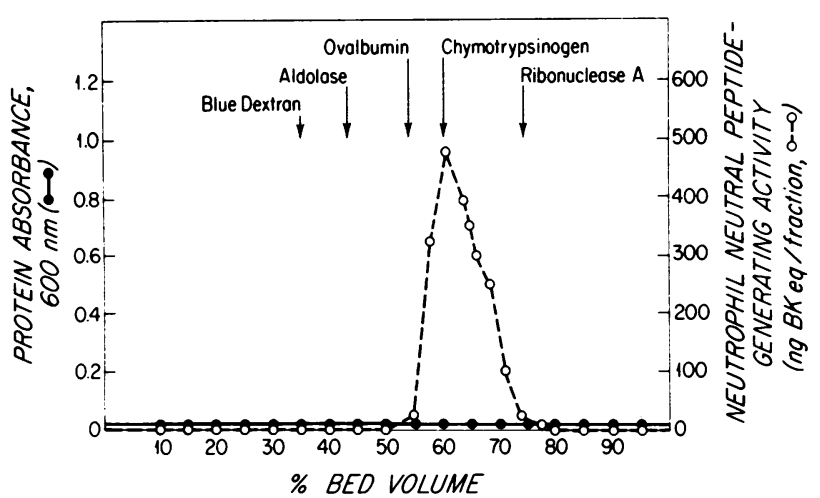

FIGURE 2 Sephadex G-100 filtration of the resolubilized neutral peptide-generating protease, after isolation by affinity chromatography and precipitation.

G-100 column equilibrated in $0.01 \mathrm{M}$ Tris, $\mathrm{pH} 7.4$, $1.0 \mathrm{M} \mathrm{NaCl}$, and run at a flow rate of $6 \mathrm{ml} / \mathrm{h}$. Fractions corresponding to $1 \%$ bed volume were collected and every fifth tube was assayed until the region of neutral peptide-generating activity was detected. In this region, every other tube was assayed. A single peak of activity was obtained corresponding to the chymotrypsinogen marker (Fig. 2).

The range of recoveries of neutral peptide-generating protease from four consecutive preparations of $10^{9}$ purified human neutrophils is presented in Table $I$. The overall recovery is $45-62 \%$ and the purification is $\cong 200$ - to 400 -fold.

Physicochemical characterization. $25 \mu \mathrm{g}$ of purified protease, was alkylated, or reduced and alkylated, and subjected to SDS-PAGE. In both reduced and unreduced gels, a predominant protein band was noted corresponding to a mol wt of $29,000-30,000$. In addition, multiple smaller bands with approximate molecular weights ranging from 11,000 to 17,000 were present in both gels, but were more prominent in the unreduced preparation. To distinguish between con- tamination and autodegradation, $100 \mu \mathrm{g}$ of the protease in $200 \mu \mathrm{l} 0.01 \mathrm{M}$ Tris, $\mathrm{pH} 7.4,1.0 \mathrm{M} \mathrm{NaCl}$ was treated with $1 \mathrm{mM}$ DFP for $12 \mathrm{~h}$ at $4^{\circ} \mathrm{C}$ and another $100 \mu \mathrm{g}$ was maintained in buffer alone. The DFP-treated and untreated protease were each dialyzed against 1 liter of distilled water for $3 \mathrm{~h}$ at $4^{\circ} \mathrm{C}$, lyophilized, and resuspended in $100 \mu \mathrm{l} 0.1 \mathrm{M}$ sodium phosphate, $\mathrm{pH} 7.2 ; 50$ $\mu \mathrm{g}$ of each were alkylated and subjected to SDS-PAGE. A single band corresponding to a mol wt of 29,00030,000 was obtained with the DFP-treated protease, whereas the untreated protease again demonstrated multiple low molecular weight materials (Fig. 3A, B). Another $100 \mu \mathrm{g}$ of protease was treated with DFP, and one-half was alkylated and the other half reduced and alkylated. SDS-PAGE revealed a single stained band corresponding to a mol wt of $29,000-30,000$ with both the reduced and unreduced protease, indicating that the neutral peptide-generating protease is composed of a single polypeptide chain (Fig. 3B, C). SDS-PAGE of $7.5 \mu \mathrm{g}$ of DFP-treated and reduced protease also revealed a single stained band corresponding to a mol wt of 29,000-30,000 (Fig. 3D).

$50 \mu \mathrm{g}$ of neutral peptide-generating protease from three different preparations was subjected to isoelectric focusing in sucrose. A $125-\mu \mathrm{l}$ portion from each fraction was assayed for neutral peptide-generating activity, and the isoelectric point for each preparation was in the pH 7.8-8.3 range with a peak at $\mathrm{pH}$ 8.0.

Functional characterization of the neutral peptidegenerating protease. The $\mathrm{pH}$ optimum for the interaction between the neutral peptide-generating protease and the plasma protein substrate was determined with $0.1 \mathrm{M}$ acetate buffers, $\mathrm{pH} 3.5-5.5 ; 0.1 \mathrm{M}$ phosphate buffers, $\mathrm{pH}$ 5.5-8.0; and $0.1 \mathrm{M}$ Tris-HCl buffers, $\mathrm{pH}$ 8.0-9.0. $20 \mu \mathrm{l}$ of substrate was added to $175 \mu \mathrm{l}$ of buffer, and the $\mathrm{pH}$ was determined before the addition of $3 \mu \mathrm{g}$ of neutral peptide-generating protease in $5 \mu \mathrm{l}$ of buffer. The reaction was carried out for $7 \mathrm{~min}$ at $37^{\circ} \mathrm{C}$, and stopped by placing the reaction mixture in an ice

TABLE I

Purification of Human Neutrophil Neutral Peptide-Generating Protease*

\begin{tabular}{|c|c|c|c|c|c|}
\hline Isolation step & Volume & Protein & $\begin{array}{c}\text { Total } \\
\text { activity }\end{array}$ & $\begin{array}{l}\text { Recovery } \\
\text { at each } \\
\text { step }\end{array}$ & Sp act \\
\hline & $m l$ & $\mu g / m l$ & ng $B K e q$ & $\%$ & $\begin{array}{l}\text { ng BKeql } \\
\mu g \text { protein }\end{array}$ \\
\hline $\begin{array}{l}\text { Elution with } 0.01 \mathrm{M} \text { Tris, } \mathrm{pH} 7.4,1 \mathrm{M} \mathrm{NaCl} \text {, } \\
\text { for } 1 \mathrm{~h} \text { at room temperature }\end{array}$ & $2-4.8$ & $6,300-10,450$ & $2,880-14,820$ & 100 & $0.1-0.5$ \\
\hline Aprotinin-affinity chromatography & $4-5.6$ & $61-300$ & $1,890-10,400$ & $51-79$ & $4.3-21.6$ \\
\hline Precipitation in $0.01 \mathrm{M}$ Tris, $\mathrm{pH} 8.0$, & & & & & \\
\hline $0.01 \mathrm{M} \mathrm{NaCl}$ & 1 & $57-270$ & $1,734-9,360$ & $87-95$ & $20.0-40.0$ \\
\hline Sephadex G-100 & 1 & $52-112$ & $1,590-8,424$ & $90-95$ & $40.0-80.0$ \\
\hline & & \multicolumn{2}{|c|}{ Overall recovery } & $45-62$ & \\
\hline
\end{tabular}

* Values represent ranges for four consecutive preparations. 


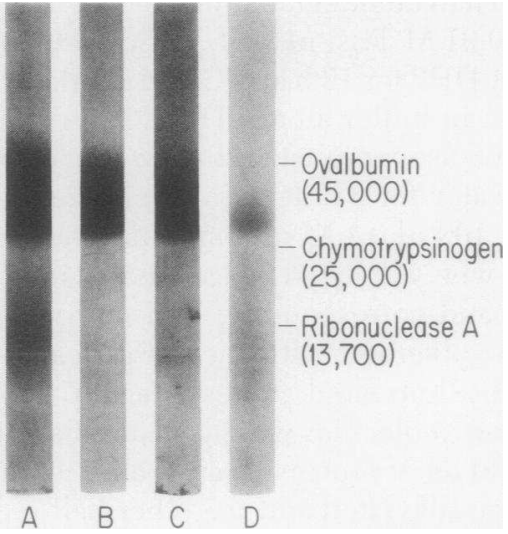

FIGURE 3 SDS-PAGE of purified neutral peptide-generating protease. $50 \mu \mathrm{g}$ of protein was applied to gels A, B, and C. A, alkylated; B, treated with $1 \mathrm{mM}$ DFP and alkylated; C, treated with $1 \mathrm{mM}$ DFP, and reduced and alkylated; D, 7.5 $\mu \mathrm{g}$ of protease treated with $1 \mathrm{mM}$ DFP, and reduced and alkylated.

bath. The full $200-\mu l$ sample was bioassayed for generation of neutral peptide. The $\mathrm{pH}$ optimum for the plasma protein substrate was $\mathrm{pH} 7.0$ (Fig. 4). When the $\mathrm{pH}$ range 6.0-8.0 was reexamined in increments of $0.4 \mathrm{pH}$ units, the $\mathrm{pH}$ optimum was again 7.0 , with the optimal range being $\mathrm{pH} 6.8-7.2$. The $\mathrm{pH}$ optimum for the action of $2 \mu \mathrm{g}$ of protease on $5 \mu \mathrm{M}$ of TAMe, assessed with the same buffers and a 60 -min incubation at $37^{\circ} \mathrm{C}$, was pH 7.7-8.0.

Dose response and kinetic experiments were carried out with the synthetic ester substrates TAMe, BAMe, and CLN. When $0.18-4.0 \mu \mathrm{g}$ of the protease was incubated with $5 \mu \mathrm{M}$ TAMe for $60 \mathrm{~min}$ at $37^{\circ} \mathrm{C}$, methanol generation varied linearly with protease concentration. The time-course of TAMe hydrolysis with $4 \mu \mathrm{g}$ of neutral peptide-generating protease and $5 \mu \mathrm{M}$ of TAMe at $37^{\circ} \mathrm{C}$ was linear throughout $75 \mathrm{~min}$, and a $60-\mathrm{min}$ interaction was employed for Lineweaver-Burk analysis of the $K_{m}$ and $V_{\max }$. A Lineweaver-Burk plot of the reciprocal of the reaction velocity, using 1,2 , and 4 $\mu \mathrm{g}$ of neutral peptide-generating protease, vs. the reciprocal of the substrate concentration gave three straight lines. The $K_{\mathrm{m}}$, estimated from the points of intersection with the abscissa, is $6.67 \mathrm{mM}$ and the $V_{\max }$ for 1,2 , and $4 \mu \mathrm{g}$ is $0.015,0.025$, and $0.05 \mu \mathrm{mol} \mathrm{MeOH} / \mathrm{ml}$ per min, respectively (Fig. 5). With BAMe the $K_{\mathrm{m}}$ was $20 \mathrm{mM}$ and the $\mathrm{V}_{\max }$ for $2 \mu \mathrm{g}$ was $0.04 \mu \mathrm{mol} \mathrm{MeOH} / \mathrm{ml}$ per min. 1-4 $\mu \mathrm{g}$ of the protease incubated with $0.4 \mathrm{mM}$ $\mathrm{CLN}$ at $30^{\circ} \mathrm{C}$ for $5 \mathrm{~min}$ generated $p$-nitrophenol linearly with time and with protease concentration. These conditions were used for the determination of $K_{\mathrm{m}}$ and $\mathrm{V}_{\max }$ with 2 and $4 \mu \mathrm{g}$ of neutral peptide-generating protease. The $K_{\mathrm{m}}$ was $0.4 \mathrm{mM}$ and the $\mathrm{V}_{\max }$ for 2 and $4 \mu \mathrm{g}$ was 0.013 and $0.025 \mu \mathrm{mol} p$-nitrophenol $/ \mathrm{ml}$ per min, respectively. (Fig. 6). $10 \mu \mathrm{g}$ of neutral peptide-generating protease released no benzoyl-tyrosine from $1.07 \mathrm{mM}$ BTEE during a 5-min incubation at room temperature, whereas $2 \mu \mathrm{g}$ of chymotrypsin yielded an activity corresponding to $61.5 \mathrm{U} / \mathrm{mg}$ (19). $10 \mu \mathrm{g}$ of neutral peptidegenerating protease released no $p$-nitroanilide from $0.002 \mathrm{mM}$ Suc-(ala) ${ }_{3}$-pNA during a 3-min time-course at room temperature, whereas $3 \mu \mathrm{g}$ of porcine elastase released $0.0014 \mathrm{mmol} p$-nitroanilide. $100 \mu \mathrm{g}$ of neutral peptide-generating protease released no elastin from $20 \mathrm{mg}$ of orcein-dyed elastin during a 90 -min incubation at $37^{\circ} \mathrm{C}$, whereas $20 \mu \mathrm{g}$ porcine elastase released $2 \mathrm{mg}$ solubilized elastin. $5 \mu \mathrm{g}$ of neutral peptide-

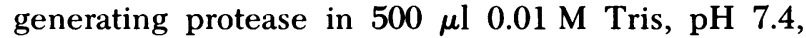
$0.15 \mathrm{M} \mathrm{NaCl}$ had no effect on the hemolytic activity of $\mathrm{C} 3$ after a 60 -min incubation at $37^{\circ} \mathrm{C}$, whereas $5 \mu \mathrm{g}$ of trypsin in $500 \mu \mathrm{l}$ of the same buffer inactivated $100 \%$ of the hemolytic C3 activity.

$N \alpha$ - $p$-tosyl-L-lysine chloromethyl ketone $\mathrm{HCl}, \mathrm{L}-1-$ tosylamide-2-phenylethyl chloromethyl ketone, and

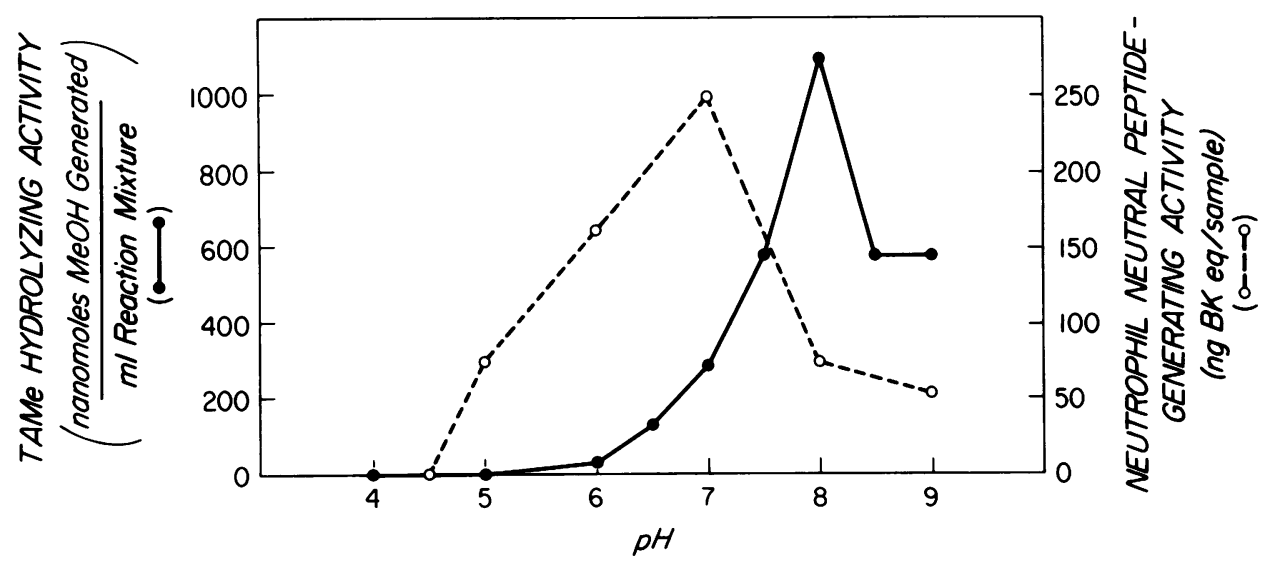

FIGURE $4 \mathrm{pH}$ profile of the activity of neutral peptide-generating protease on its native plasma protein substrate and on TAMe. 


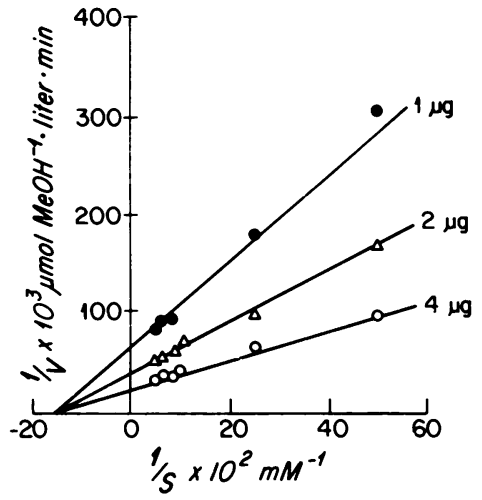

FiguRE 5 Lineweaver-Burk analysis of the hydrolysis of TAMe by purified neutral peptide-generating protease.

acetyl-(L-alanine) ${ }_{2}$-proline-valine chloromethyl ketone, each at $1 \mathrm{mM}$, and DFP at $0.001-1 \mathrm{mM}$ were analyzed for the ability to inhibit the action of $3 \mu \mathrm{g}$ of neutral peptide-generating protease on $250 \mu$ g partially purified plasma protein substrate during a 30 -min incubation at $37^{\circ} \mathrm{C}$. DFP $(0.1 \mathrm{mM})$ gave $\cong 50 \%$ inhibition and $1 \mathrm{mM}$ DFP gave complete inhibition of neutral peptide generation during a 30 -min incubation at $37^{\circ} \mathrm{C}$. None of the other agents inhibited the neutral peptidegenerating protease, although $1 \mathrm{mM} \mathrm{N}-\alpha$-p-tosyl-Llysine chloromethyl ketone $\mathrm{HCl}$ inhibited TAMehydrolyzing activity of $2 \mu \mathrm{g}$ of trypsin by $50 \%$, and $1 \mathrm{mM}$ L - 1 - tosylamide - 2 - phenylethyl chloromethyl ketone inhibited BTEE-hydrolyzing activity of $2 \mu \mathrm{g}$ of chymotrypsin by $50 \%$. $0.1 \mathrm{mM}$ acetyl-(L-alanine) ${ }_{2}$-prolinevaline chloromethyl ketone totally inhibited hydrolysis of $N$-t-Boc-L-alanine $p$-nitrophenyl ester by $5 \mu \mathrm{g}$ of porcine pancreatic elastase.

\section{DISCUSSION}

A neutrophil protease, which generates a neutral peptide from a plasma protein substrate, has been purified to homogeneity. The starting material for purification was obtained from purified human neutrophils by homogenization, sedimentation by low-speed centrifugation and high salt elution of the insoluble material. The previous observations (11) that elution recovers $>90 \%$ of the neutral peptide-generating activity recognized in the pellet or in the unfractionated homogenate and that the protease is soluble in high salt concentrations and insoluble in low salt concentrations were utilized to develop a three-step isolation procedure. Affinity chromatography with aprotininSepharose yielded a single peak of neutral peptidegenerating activity upon elution with $2 \mathrm{M} \mathrm{NaCl}$ at acidic pH (Fig. 1) and gave approximately a 40-fold increase in specific activity (Table I). Precipitation at slightly alkaline $\mathrm{pH}$ and low ionic strength, followed by sedimentation by ultracentrifugation and re-

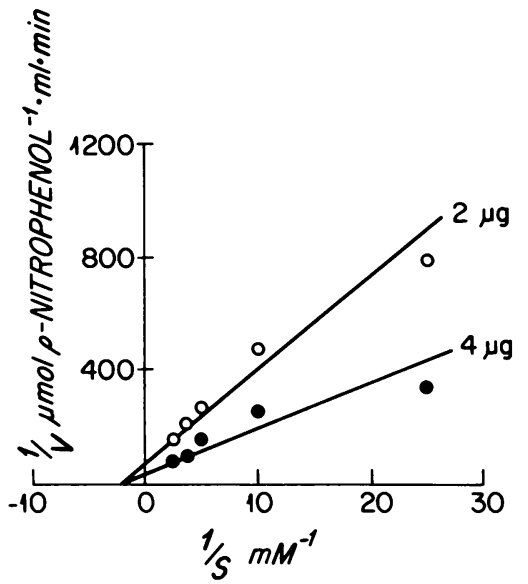

FIGURE 6 Lineweaver-Burk analysis of the hydrolysis of CLN by the purified neutral peptide-generating protease.

solubilization in $0.01 \mathrm{M}$ Tris, $\mathrm{pH} 7.4,1 \mathrm{M} \mathrm{NaCl}$ gave a further fourfold increase in specific activity. A further twofold increase in specific activity was achieved by Sephadex G-100 filtration in a high salt concentration (Fig. 2). The overall recovery of the neutral peptidegenerating protease from four different consecutive preparations ranged from 45 to $62 \%$ relative to the activity in the starting eluate of the neutrophil fraction obtained by low-speed sedimentation. The increase in specific activity was 200 - to 400 -fold. The three-step purified neutral peptide-generating protease was soluble in physiological buffers, suggesting that its interaction with one or more constituents in the cell eluate was responsible for its initial insolubility in the same buffers. If $50 \%$ recovery is assumed, the quantity of soluble neutral peptide-generating protease in $10^{6}$ human neutrophils is $0.1-0.2 \mu \mathrm{g}$, as compared to $1-2$ $\mu \mathrm{g}$ of cathepsin G and 3-4 $\mu \mathrm{g}$ of elastase (28).

The observation that the purified protease, subjected to reduction and alkylation and then SDS-PAGE, gave a major protein band of $29,000-30,000 \mathrm{~mol} w \mathrm{w}$ and additional bands of lesser size was attributed to autodegradation. The additional bands of lesser size than the protease were even more prominent in the alkylated unreduced sample, and their appearance was entirely prevented by treatment with DFP before alkylation and SDS-PAGE (Fig. 3A, B). DFP treatment followed by alkylation alone or reduction and alkylation gave a single protein band on SDS-PAGE for both preparations of $29,000-30,000 \mathrm{~mol} \mathrm{wt}$, indicating that the neutral peptide-generating protease is composed of a single polypeptide chain (Fig. 3B-D). The isoelectric point determined in sucrose gradients and assessed by functional analysis was $\mathrm{pH}$ 7.8-8.3 with a peak of $\mathrm{pH}$ 8.0.

The previous finding that the partially purified neutral peptide-generating protease was inhibited by 
DFP, soybean trypsin inhibitor, and lima bean trypsin inhibitor, suggested that it might be a tryptic serine protease $(11,12)$. The $\mathrm{pH}$ optimum for neutral peptide generation by the purified protease was $6.8-7.2$ and for TAMe hydrolysis was 7.7-8.0 (Fig. 4). Thus on both the synthetic and the natural substrate this neutrophil enzyme is of the neutral protease class. The $\mathrm{K}_{\mathrm{m}}$ of the purified protease for TAMe (Fig. 5) and BAMe was 6.67 and $20 \mathrm{mM}$, with a $\mathrm{V}_{\max }$ of 0.013 and $0.02 \mu \mathrm{mol} \mathrm{MeOH} / \mathrm{ml}$ per min per $\mu \mathrm{g}$ of protein, respectively. The $K_{\mathrm{m}}$ for CLN was $0.4 \mathrm{mM}$, and the $\mathrm{V}_{\max }$ was $0.0065 \mu \mathrm{mol} p$ nitrophenol $/ \mathrm{ml}$ per min per $\mu$ g of protein (Fig. 6). The neutral peptide-generating protease failed to cleave BTEE at five times the enzyme concentration at which chymotrypsin was esterolytic. The neutral peptidegenerating protease did not hydrolyze either Suc(ala) ${ }_{3}$-pNA or solubilized orcein-dyed elastin at three to five times the concentration at which porcine elastase cleaved these substrates. Finally, the enzyme did not hemolytically inactivate $\mathrm{C}$.3 at a concentration at which trypsin gave $100 \%$ inactivation.

The human neutrophil neutral peptide-generating protease appears to be a neutral protease distinct from those previously described as elastase, cathepsin G, and collagenase. Although these three activities appear with the lysosomal enzyme markers in subcellular fractionation (29), the neutral peptide-generating protease is not detectable in the lysosomal fraction $(11,12)$, and sediments at low speed with the cell debris. Collagenase has a mol wt of $\cong 70,000(8)$, and thus, is considerably larger than the others which fall in the 30,000mol wt range. The neutral peptide-generating protease, like cathepsin $\mathrm{G}$ and elastase, is composed of a single polypeptide chain. It differs in its isoelectric point, which is moderately alkaline rather than highly cationic, and in its substrate specificity. In contrast to cathepsin G, it hydrolyzes TAMe and BAMe but fails to hydrolyze BTEE (30). It has no activity on two substrates of elastase, Suc-(ala $)_{3}$-pNA or orcein-elastin and its neutral peptide-generating activity is not diminished by acetyl-(L-alanine $)_{2}$-proline-valine chloromethyl ketone, an elastase inhibitor (13). The purified neutral peptide-generating protease also hydrolyzes CLN in addition to TAMe and BAMe, and thus has an apparent preference for basic peptide bonds, whereas cathepsin $\mathrm{G}$ exhibits a preference for aromatic amino acids and leucyl bonds, and elastase for alanyl peptide bonds (31).

\section{ACKNOWLEDGMENTS}

We gratefully acknowledge the excellent technical assistance of Ms. Carol Kaempfer.

This work was supported by grants AI-07722, AM-05577, AI-10356, HL-19777, and RR-05669 from the National Institutes of Health.

\section{REFERENCES}

1. Bretz, U., and M. Baggiolini. 1974. Biochemical and morphological characterization of azurophilic and specific granules of human neutrophilic polymorphonuclear leukocytes. J. Cell Biol. 63: 251-269.

2. Starkey, P. M., and A. J. Barrett. 1976. Human lysosomal elastase, catalytic and immunological properties. Biochem. J. 155: 265-271.

3. Schmidt, W., and K. Havemann. 1974. Isolation of elastase-like and chymotrypsin-like neutral proteases from human granulocytes. Hoppe-Seyler's Z. Physiol. Chem. 355: 1077-1082.

4. Plow, E. F., and T. S. Edgington. 1975. An alternative pathway of fibrinolysis. I. The cleavage of fibrinogen by leukocyte proteases at physiological pH.J. Clin. Invest. 56: $30-38$.

5. Pryce-Jones, R. H., J. Saklatuala, and G. C. Wood. 1974. Neutral proteases from the polymorphonuclear leukocytes of human rheumatoid synovial fluid. Clin. Sci. Mol. Med. 47: 403-414.

6. Rindler-Ludwig, R., and H. Brannsteiner. 1975. Cationic proteins from human neutrophil granulocytes. Evidence for their chymotrypsin-like properties. Biochim. Biophys. Acta. 379: 606-617.

7. Starkey, P. M., and A. J. Barrett. 1976. The degradation of articular collagen by neutrophil proteinases. Biochem. J. 155: 273-278.

8. Ohlsson, K., and I. Olsson. 1973. The neutral proteases of human granulocytes. Isolation and partial characterization of two granulocyte collagenases. Eur.J. Biochem. 36: $473-481$.

9. Weissman, G., P. Dukor, and R. Zurier. 1971. Effect of cyclic AMP on release of lysosomal enzymes from phagocytes. Nat. New Biol. 231: 131-135.

10. Showell, H., R. Freer, S. Zigmond, E. Schiffmann, S. Aswanitumar, B. Corcoran, and E. Becker. 1976. The structure-activity relations of synthetic peptides as chemotactic factors and inducers of lysosomal enzyme secretion for neutrophils. J. Exp. Med. 143: 1154-1169.

11. Wintroub, B. U., E. J. Goetzl, and K. F. Austen. 1977. A neutrophil-dependent pathway for the generation of a neutral peptide mediator. II. Subcellular localization of the neutrophil protease. Immunology. 33: 41-49.

12. Wintroub, B. U., E. J. Goetzl, and K. F. Austen. 1974. A neutrophil-dependent pathway for the generation of a neutral peptide mediator. J. Exp. Med. 140: 812-824.

13. Powers, J. C., B. F. Grupton, A. D. Hartley, N. Nishino, and R. J. Whitley. 1977. Specificity of porcine pancreatic elastase, human leukocyte elastase and cathepsin G. Inhibition with peptide chloromethyl ketones. Biochim. Biophys. Acta. 484: 156-166.

14. Tack, B. F., and J. W. Prahl. 1976. Third component of human complement: purification from plasma and physicochemical characterization. Biochemistry. 15: 4513-4521.

15. Siegelman, A., A. Carlson, and T. Robertson. 1962. Investigation of serum trypsin and related substances: the quantitative demonstration of trypsin-like activity in human blood serum by a micromethod. Arch. Biochem. Biophys. 97: 159-163.

16. Colman, R., L. Mattler, and S. Sherry. 1969. Studies on the prekallikrein-kallikrein enzyme system of human plasma. I. Isolation and purification of plasma kallikreins. J. Clin. Invest. 48: 11-22.

17. Spragg, J. 1978. Specific functional and immunologic assay of plasma plasminogen in hereditary angioedema 
treated with tranexamic acid and in normal subjects. $J$. Immunol. 120: 592-598.

18. Silverstein, R. M. 1973. The plasmin-catalysed hydrolysis of $\mathrm{N} \alpha$-CBZ-L-lysine-p-nitrophenyl ester as substrate. Anal. Biochem. 65: 500-506.

19. Hummel, B. C. W. 1959. A modified spectrophotometric determination of chymotrypsin, trypsin and thrombin. Can. J. Biochem. Physiol. 37: 1393-1399.

20. Visser, L., and E. Blout. 1972. The use of p-nitrophenyl$\mathrm{N}$-tert-butyloxycarboxyl-L-alaninate as substrate in elastase. Biochim. Biophys. Acta. 268: 257-260.

21. Bieth, J., B. Spiess, and C. Wermuth. 1974. The synthesis and analytical use of a highly sensitive and convenient substrate for elastase. Biochem. Med. 11: 350-357.

22. Sachar, L., K. Winter, N. Sicher, and S. Frankel. 1955. Photometric method for estimation of elastase activity. Proc. Soc. Exp. Biol. Med. 90: 323-326.

23. Ruddy, S., and K. F. Austen. 1969. C3b inactivator of man. I. Hemolytic measurement by inactivation of cellbound C3. J. Immunol. 102: 533-543.

24. ole-MoiYoi, O., J. Spragg, and K. F. Austen. 1978. Inhibition of human urinary kallikrein (urokallikrein) by antienzyme Fab. J. Immunol. 121: 66-71.

25. Lowry, O. H., N. H. Rosebrough, A. L. Farr, and R. J. Randall. 1951. Protein measurement with the Folin phenol reagent. J. Biol. Chem. 193: 265-275.
26. Wasserman, S. I., and K. F. Austen. 1977. Identification and characterization of arylsulfatase $A$ and $B$ of the rat basophil leukemia tumor.J. Biol. Chem. 252: 7074-7080.

27. Weber, K., and M. Osborn. 1969. The reliability of molecular weight determinations by dodecyl sulfatepolyacrylamide gel electrophoresis. J. Biol. Chem. 244: 4406-4412.

28. Ohlsson, K. 1978. Microbial aggregation induced by neutrophil chymotrypsin-like cationic protein. In Neutral Proteases of Human Polymorphonuclear Leukocytes. K. Havemann and A. Janoff, editors. Urban and Schwarzenberg, Inc., Baltimore. 38 .

29. DeWald, B., R. Rindler-Ludwig, U. Bretz, and M. Baggiolini. 1975. Subcellular localization and heterogeneity of neutral proteases in neutrophilic polymorphonuclear leukocytes. J. Exp. Med. 141: 707-723.

30. Feinstein, G., and A. Janoff. 1975. A rapid method for purification of human granulocyte cationic neutral proteases: purification and characterization of human granulocyte chymotrypsin-like enzyme. Biochim. Biophys. Acta. 403: 477-492.

31. Zimmerman, M., and B. M. Ashe. 1977. Substrate specificity of the elastase and the chymotrypsin-like enzyme of the human granulocyte. Biochim. Biophys. Acta. 480: 241-245. 